\title{
HEPATICS ALTERATIONS AND GENOTOXIC EFFECTS OF Croton cajucara BENTH (SACACA) IN DIABETIC RATS
}

\author{
Graziella RODRIGUES ${ }^{1,2}$, Éder MARCOLIN ${ }^{1,2}$, Silvia BONA ${ }^{1,2}$, Marilene PORAWSKI', , \\ Mauricio LEHMANN ${ }^{1}$ and Norma Possa MARRONI ${ }^{1,2}$
}

\begin{abstract}
Context - Croton cajucara Benth is a plant found in Amazonia, Brazil and the bark and leaf infusions of this plant have been popularly used to treat diabetes and hepatic disorders. Objectives - This study investigated effects hepatics alterations and genotoxic and antidiabetic effect of Croton cajucara Benth bark extracts treatment in streptozotocin-induced diabetic rats. Methods - Male Wistar rats were divided into six groups: control rats; control rats treated with Croton cajucara Benth extract during 5 and 20 days; diabetic rats, and diabetic rats treated with Croton cajucara Benth during 5 and 20 days. Diabetes was induced by a single intraperitoneal injection of streptozotocin $(70 \mathrm{mg} / \mathrm{kg})$. Eight weeks later we measured glucose, triglyceride, cholesterol and hepatic transaminases on blood. The bone marrow micronucleus assay was used to assess the genotoxic activity of Croton cajucara Benth. Results - Treatment with aqueous extrat of Croton cajucara was able to significantly reduce levels of triglycerides in diabetic animals, however, did not modify significantly the levels of glucose and cholesterol in these animals. There was no significant elevation in liver transaminases in the control group treated with Croton cajucara Benth, as there was no genotoxic effect of treatment in this model. Our results did not show a significant effect on glucose and cholesterol reduction, the treatment was able to significantly reduce triclycerides plasmatic level. There was no significant alterations on hepatic transferase in the animals from the control group treated with Croton cajucara Benth. It was observed no genotoxic effect of the treatment in the model studied. Conclusion-In this study Croton cajucara bark extract showed absence of hepatotoxicity in this animal model and presented a hypolipidemic activity, and could be used to reverse dyslipidemia associated with diabetes and to prevent the cardiovascular complications that are very prevalent in diabetic patients.
\end{abstract}

HEADINGS - Drug-induced liver injury. Diabetes mellitus. Croton, toxicity. Rats.

\section{INTRODUCTION}

The Amazonian region, because of its large biodiversity and popular culture, is characterized by the use of medicinal plants for treatment of various diseases. However, the indiscriminate use of some plant species may lead to serious problems to the human health.

Croton cajucara Benth - $\mathrm{CcB}$ (of the Euphorbiacea family), commonly known as Sacaca, is a shrubby plant found in Amazonia, North Brazil ${ }^{(5,28)}$, whose bark and leaf infusions have been popularly used to treat diabetes, diarrhea, malaria, fever, gastrointestinal, renal and hepatic disorders, as well as in the control of cholesterolemia ${ }^{(11,15)}$. The wide use of Sacaca for medical purposes in North Brazil and, now, in the Southeast and South regions, is associated with the appearance of numerous clinical cases where side effects are seen, many of which connected with the plant's hepatotoxicity due to continued intake.
In Belém, PR, north of Brazil, it is popularly known that the steady intake of $\mathrm{CcB}$ leaves is beneficial because it causes a healthy weight loss. It is also known that the plant can be toxic. Nevertheless, such awareness is not strong enough to prevent its use, and people feel encouraged to take it, feeling that the benefits outweigh the damages ${ }^{(18,19,20,29)}$.

Indeed, cases of acute, chronic and fatal hepatitis were reported in the Amazonian region and in other regions of the country in patients who made use of Sacaca to lose weight and reduce cholesterol levels ${ }^{(19,20)}$.

In the School Hospital of the "Universidade Federal do Pará", Belém, PR, there is a significant documented history of people afflicted by liver disorders who were drinking $\mathrm{CcB}$ leaf teas in long-lasting diets for weight loss. The connection between hepatitis and Sacaca became remarkable in the Amazonian region, particularly after this plant began to be sold for the purposes of weight loss and cholesterol reduction ${ }^{(4,14)}$.

${ }^{1}$ Universidade Luterana do Brasil, Canoas, RS, Brazil; ${ }^{2}$ Hospital de Clínicas de Porto Alegre, RS, Brazil; ${ }^{3}$ Pontifícia Universidade Católica, Porto Alegre, RS, Brazil. Correspondence: Dr. Norma Possa Marroni, Rua José Kanan Aranha, 102 - 91760-470 - Porto Alegre, RS, Brazil - E-mail: nmarroni@terra.com.br 
The possibility of developing hepatotoxicity may be related to the susceptibility of the liver to external agents, mainly chemical ones, to the high level of these substances in the organ, its high metabolic activity and its anatomic localization, as an intermediate agent between the places of absorption and systemic circulation, working as a filter and as an entry point of several substances ingested ${ }^{(22)}$.

A study performed in 2004, Amazonian people who used Sacaca for 36 months documented 25 cases of hepatoxicity ascribed to Sacaca consumption, with evidence that 21 people had acute hepatitis, 3 chronic hepatitis, and 1 fulminating hepatitis ${ }^{(27)}$.

Many traditional plants have been claimed to be useful for the control of problems caused by hyperglycemia ${ }^{(3,21)}$.

The pharmacological activity of the bark extract main component, trans-dehidrocrotonine (t-DCTN), has been extensively studied ${ }^{(17,26)}$.

Rats treated with t-DCTN $(50 \mathrm{mg} / \mathrm{kg})$ showed a significant reduction in the streptozotocin-induced increase in blood glucose levels as well as in the ethanol-induced increase in blood triglycerides ${ }^{(26)}$. This compound demonstrated a significant hypoglycemic activity in alloxan-induced diabetic rats but not in normal rats. The drug also effectively lowered the blood sugar levels in glucose fed normal rats ${ }^{(7)}$. Hyperlipidemic mice treated with $\mathrm{CcB}$ bark aqueous infusion had the level of triglycerides reduced and the level of cholesterol redistributed ${ }^{(3)}$. In vivo studies confirmed that t-DCTN is not genotoxic nor cytotoxic to mice bone marrow cells $s^{(1,25)}$.

The aim of this work was to determine hepatic alterations, genotoxic activities and the potential effects of $\mathrm{CcB}$ bark extract in long term (chronic) diabetic rats.

\section{METHODS}

\section{Plant material}

Bark fragments of Croton cajucara Benth were collected in Santarém, North Brazil. The bark ( $5 \mathrm{~g})$ was ground and mixed with boiling water $(100 \mathrm{~mL})$ to provide a $5 \%$ aqueous extract. After 10 minutes, the mixture was filtered with filter paper and the extract was administered to the rats.

\section{Animals}

The experimental procedures complied with the rules established by the "Research in Health and Animal Rights" according to the Commission of Research and Ethics in Health of the Research and Postgraduate Group of the "Hospital de Clínicas de Porto Alegre (9) (HCPA), Universidade Federal do Rio Grande do SUL (UFRGS)", Porto Alegre, RS, Brazil.

Fifty male Wistar rats weighing 200-300 g were used. They were obtained from the Experimental Animals Breeding Colony of the "Instituto de Ciências Básicas da Saúde, UFRGS" (CREAL). They were kept at the Animal Experimentation Unit of the Research Center of the HCPA, in plastic boxes measuring $47 \times 34 \times 18 \mathrm{~cm}$ lined with wood chips, in a 12-hour dark/light cycle (light from 7 a.m. to 19 p.m.) at a temperature of $22 \pm 4 \mathrm{C}$.

\section{Groups and treatment protocols}

The rats were randomly divided into six groups. In three groups, diabetes was induced by a single intraperitoneal (i.p.) injection of streptozotocin $(70 \mathrm{mg} / \mathrm{kg}$ body weight; Sigma Chemical) in freshly prepared $10 \mathrm{mmol} / \mathrm{L}$ sodium citrate, $\mathrm{pH}$ 4.5. Five days after streptozotocin injection, plasma glucose concentration was measured using retro-orbital blood samples obtained from rats after overnight food deprivation. A plasma glucose level $>250 \mathrm{mg} / \mathrm{dL}$ was considered indicative of diabetes.

The experimental groups comprised: I - normal control group $(\mathrm{Co}: \mathrm{n}=10)$ received $1,5 \mathrm{~mL}$ of distilled water administered intragastric (I.G.); II - group treated with $\mathrm{CcB}$ for 5 days $(\mathrm{CcB}-5 \mathrm{D}: \mathrm{n}=10)$ : $1,5 \mathrm{~mL}$ of the $\mathrm{CcB}$ extract I.G. during the last 5 days before killed; III - group treated with $\mathrm{CcB}$ for 20 days (CcB-20D: $\mathrm{n}=10): 1,5 \mathrm{~mL}$ of the $\mathrm{CcB}$ extract I.G. for 20 days before killed; IV - diabetic group (DM: $\mathrm{n}=10$ ): $1,5 \mathrm{~mL}$ of distilled water I.G.; V - diabetic group treated with $\mathrm{CcB}$ for 5 days $(\mathrm{DM}+\mathrm{CcB}-5 \mathrm{D}: \mathrm{n}=10)$ : $1,5 \mathrm{~mL}$ of the $\mathrm{CcB}$ extract I.G. during the last 5 days before killed; and VI - diabetic group treated with $\mathrm{CcB}$ for 20 days $(\mathrm{DM}+\mathrm{CcB}-20 \mathrm{D}: \mathrm{n}=10) 1,5 \mathrm{~mL}$ of the $\mathrm{CcB}$ extract I.G. for 20 days before killed.

\section{Biochemical analysis}

All animals were killed 8 weeks after streptozotocin administration. The rats were anaesthetized with $2 \%$ xylazine hydrochloride $(50 \mathrm{mg} / \mathrm{kg})$ and ketamine hydrochloride $(100$ $\mathrm{mg} / \mathrm{kg}$ ) i.p., and a sample of venous blood was collected in two aliquots from the orbital net for determination of glycemia, triglycerides, and cholesterol levels (Labtest kits) and for aspartate aminotransferase (AST), alanine aminotransferase (ALT), and alkaline phosphatase (AP) activities (performed by the Laboratory of Pathology of HCPA).

\section{Micronucleus assay (MN)}

The animals of all groups were killed by cervical dislocation. The MNs were prepared according to the method of MacGregor et al. ${ }^{(16)}$. Briefly, the femurs of each animal were dissected out, and the bone marrow was flushed out into fetal calf serum (FCS) separately. The cells were pelleted by centrifugation and the excess of supernatant was discarded. The pellet and 0.5 $\mathrm{mL}$ of supernatant were mixed thoroughly. Smears were drawn onto precleaned coded slides using a drop of the resultant suspension in FCS. The slides were air-dried for 24 hours and stained with Leishman solution. Two thousand polychromatic erythrocytes were analyzed per rat. The slides were scored blindly using a light microscope with a 100x immersion objective. Data regarding the polychromatic and normochromatic erythrocyte (PCE/NCE) ratio were also collected, in which a minimum of 400 erythrocytes per animal were scored.

The results were expressed as mean values \pm SEM. The data were compared by analysis of variance (ANOVA); when the analysis indicated the presence of a significant difference, the means were compared with the Student Newmann Keuls test. For micronucleus test, the means were compared with the Tukey test and expressed as mean \pm SDM. Significance was accepted at $\mathrm{P}<0.05$. 


\section{RESULTS}

\section{Biochemical analysis}

Blood plasma glucose, triglycerides, and cholesterol levels in streptozotocin-treated rats were significantly higher than in the $\mathrm{Co}$ and in $\mathrm{CcB}$-treated animals (CcB-5D and CcB-20D). Glucose and cholesterol levels were not affected by $\mathrm{CcB}$ treatment in diabetic animals. On the other hand, triglyceride concentration in the plasma of streptozotocin-treated rats was significantly lower after treatment with $\mathrm{CcB}$ for 5 and 20 days (Table 1 ).

TABLE 1. Glucose, triglycerides and cholesterol in the blood plasma

\begin{tabular}{lccc}
\hline Group & $\begin{array}{c}\text { Glucose } \\
(\mathrm{mg} / \mathrm{dL})\end{array}$ & $\begin{array}{c}\text { Triglycerides } \\
(\mathrm{mg} / \mathrm{dL})\end{array}$ & $\begin{array}{c}\text { Cholesterol } \\
(\mathrm{mg} / \mathrm{dL})\end{array}$ \\
\hline Co & $215,97 \pm 9,86 \mathrm{a}$ & $91,58 \pm 12,41 \mathrm{~b}$ & $51,85 \pm 5,69 \mathrm{a}$ \\
CcB-5D & $211,8 \pm 17,09 \mathrm{a}$ & $90,2 \pm 8,11 \mathrm{~b}$ & $55,6 \pm 4,86 \mathrm{a}$ \\
CcB-20D & $232,08 \pm 24,49 \mathrm{a}$ & $89,66 \pm 12,12 \mathrm{~b}$ & $56,08 \pm 3,65 \mathrm{a}$ \\
DM & $468,8 \pm 36,12 \mathrm{~b}$ & $227,3 \pm 54,22 \mathrm{a}$ & $85,1 \pm 4,86 \mathrm{~b}$ \\
DM+CcB-5D & $406 \pm 15,77 \mathrm{~b}$ & $83,3 \pm 9 \mathrm{~b}$ & $72,8 \pm 2,50 \mathrm{~b}$ \\
DM+CcB-20D & $418,5 \pm 22,82 \mathrm{~b}$ & $91,34 \pm 24,34 \mathrm{~b}$ & $71,6 \pm 6,12 \mathrm{~b}$ \\
\hline Values are mean + SEM, $\mathrm{n}=10$. Means wirhour a common letrer differ, $P<0.05$ &
\end{tabular}

The biochemical analysis showed that the diabetic group had higher ALT and AP levels than the control group. Treatment reduced ALT level only in diabetic rats. ALT, AST and $\mathrm{AP}$ were not affected by $\mathrm{CcB}$ treatment in non-diabetic animals (Table 2).

TABLE 2. Effect of streptozotocin induced diabetes and Croton cajucara bark extract $(\mathrm{CcB})$ on serum enzymes activities: ALT, AST and AP

\begin{tabular}{lccc}
\hline Group & AST $(\mathbf{U} / \mathbf{L})$ & ALT $(\mathbf{U} / \mathbf{L})$ & AP $(\mathbf{U} / \mathbf{L})$ \\
\hline CO & $153,90 \pm 12,30^{\mathrm{a}}$ & $53,20 \pm 1,86^{\mathrm{a}}$ & $136,20 \pm 10,07^{\mathrm{a}}$ \\
CcB-5D & $149,4 \pm 11,30^{\mathrm{a}}$ & $66,5 \pm 10,63^{\mathrm{a}}$ & $168,2 \pm 18,75^{\mathrm{a}}$ \\
CcB-20D & $131,73 \pm 12,60^{\mathrm{a}}$ & $59,45 \pm 5,28^{\mathrm{a}}$ & $137,45 \pm 9,96^{\mathrm{a}}$ \\
DM & $201,8 \pm 41,63^{\mathrm{a}}$ & $154,1 \pm 38,85^{\mathrm{b}}$ & $411,3 \pm 46,08^{\mathrm{b}}$ \\
DM+CcB-5D & $127,3 \pm 15,53^{\mathrm{a}}$ & $71,33 \pm 8,57^{\mathrm{a}}$ & $330,4 \pm 93,49^{\mathrm{b}}$ \\
$\mathrm{DM}+\mathrm{CcB}-20 \mathrm{D}$ & $143,3 \pm 21,95^{\mathrm{a}}$ & $99,8 \pm 10,82^{\mathrm{a}}$ & $436,2 \pm 46,74^{\mathrm{b}}$ \\
\hline
\end{tabular}

Values are mean $\pm \mathrm{SEM}, \mathrm{n}=10$. Means without a common letter differ, $P<0.05$

\section{Genotoxic potential}

Table 3 displays the micronucleus frequency in the animals treated in vivo. Although the diabetic rats increased PCEs as compared to the controls, significant differences were not observed between the groups. Similarly, no difference in the PCE/NCE ratio was found in any of the groups analyzed.
TABLE 3. Micronucleated polychromatic erythrocytes frequency (MNPCEs) and rate PCE/NCE in the bone marrow of diabetic and non-diabetic male rats treated with Croton cajucara Benth stem bark aqueous solution

\begin{tabular}{lccc}
\hline Group & $\begin{array}{c}\text { Number of PCEs } \\
\text { analysed }\end{array}$ & $\begin{array}{c}\text { Number of } \\
\text { micronucleated } \\
\text { PCEs in 2000 } \\
\text { PCEs } \pm \text { ST }^{*}\end{array}$ & PCE/NCE ratio* \\
\hline CO & 20.000 & $3,88 \pm 2,70^{\mathrm{a}}$ & $1,11 \pm 0,42^{\mathrm{b}}$ \\
CcB-5D & 20.000 & $6,11 \pm 1,27^{\mathrm{a}}$ & $1,13 \pm 0,58^{\mathrm{b}}$ \\
CcB-20D & 20.000 & $3,25 \pm 2,25^{\mathrm{a}}$ & $1,14 \pm 0,43^{\mathrm{b}}$ \\
DM & 20.000 & $7,25 \pm 4,33^{\mathrm{a}}$ & $0,93 \pm 0,40^{\mathrm{b}}$ \\
$\mathrm{DM}+\mathrm{CcB}-5 \mathrm{D}$ & 20.000 & $6,44 \pm 3,47^{\mathrm{a}}$ & $1,12 \pm 0,46^{\mathrm{b}}$ \\
$\mathrm{DM}+\mathrm{CcB}-20 \mathrm{D}$ & 20.000 & $4,22 \pm 2,33^{\mathrm{a}}$ & $1,02 \pm 0,45^{\mathrm{b}}$ \\
\hline
\end{tabular}

*ST: standard deviation. Values with the same letter do not differ statistically (one-way ANOVA; Tukey post-hoc test, $P<0.05$ )

\section{DISCUSSION}

A vegetal species from Amazon region, $\mathrm{CcB}$ is widely used by the local population to treat gastrointestinal conditions, but it can cause hepatic dysfunction and in some cases even fatal hepatitis ${ }^{(12,22)}$. Indeed, cases of toxic hepatitis have been reported in several hospitals in Belém, PA, because of excessive consumption of extremely strong $\mathrm{CcB}$ tea ${ }^{(17)}$.

Here the effects of a Sacaca herbal extract were evaluated in rat livers. The administration of Sacaca herbal extract in this trial was not able to cause any kind of alteration in the livers with 14 days of drug administration. However, hepatocellular alterations were identified in some animals when the extract was administered for 28 days, and all the animals treated with the drug for 56 days presented hepatocellular necrosis, similar to acute hepatitis. Therefore, it is concluded that Sacaca toxicity is dose-dependent ${ }^{(10)}$.

The liver plays an important role in the digestion, metabolism, and storage of nutrients. Liver injury due to pharmacological treatment plays a significant role ${ }^{(8)}$. Hepatic damage results in increased concentrations of AST, ALT and AP. The high concentration of serum enzymes such as AST and ALT is generally regarded as one of the sensitive markers of hepatic damage ${ }^{(30)}$. In this study, the increased concentration of ALT, AST and AP in diabetic animals returned to the control index after treatment with $\mathrm{CcB}$ bark extract, but AP concentration remained elevated. Similar results are observed in studies with $\mathrm{CCl}_{4}$ intoxication and treatment with Rhoicissus tridentate ${ }^{(23)}$ and Cytisus scoparius ${ }^{(24)}$. Reduction in the levels of serum aminotransferase (ALT and AST) and lactate dehydrogenase (LH) towards the respective normal values by plant extracts indicates stabilization of the plasma membranes, as well as repair of hepatic tissue damage ${ }^{(24)}$. The non-diabetic animals treated with $\mathrm{CcB}$ bark extract did not show increase in transaminases and AP concentration, indicating the absence of hepatotoxicity in this animal model.

In the present study, it was apparent that the $\mathrm{CcB}$ bark extract did not have substantial effect on blood glucose and cholesterol levels. This observation differs from the results of Silva et al. ${ }^{(26)}$, who found a hypoglycemic effect of $\mathrm{CcB}$ when given to streptozotocin-diabetic rats. These apparently conflicting results 
are explained by the fact that, in our study, $\mathrm{CcB}$ was given in bark aqueous extract form after diabetes had been established, whereas in the previous study the t-DCTN was administrated before the induction of diabetes or $72 \mathrm{~h}$ after the induction. On the other hand, treatment with $\mathrm{CcB}$ bark extract significantly reduced blood triglyceride levels in diabetic rats, and did not have effect on blood triglycerides in non-diabetic rats. Other studies suggest that TG itself is independently related to coronary heart disease ${ }^{(2,6)}$, and most of the anti-hypercholesterolemic drugs do not decrease TG levels ${ }^{(13)}$, but $\mathrm{CcB}$ extract treatment returned the triglycerides to control values. This suggests that $\mathrm{CcB}$ bark extract has a hypolipidemic activity, and could be used to reverse dyslipidemia associated with diabetes and to prevent the cardiovascular complications that are very prevalent in diabetic patients.

The bone marrow $\mathrm{MN}$ was used to assess the genotoxic activity of $\mathrm{CcB}$. The results show that the aqueous extract of $\mathrm{CcB}$ bark did not induce any increase in chromosomal damage (chromosomal loss or breakage) when administered to rats with and without diabetes for periods of 5 and 20 days, as compared to the respective control groups (Table 3 ).

Although the genotoxic activity of the plant species has been little studied, $\mathrm{CcB}$ has been described in the literature as not having any genotoxic activity, which corroborates the results obtained in the present study. In fact, Santos et al. ${ }^{(25)}$ evaluated the genotoxic activity of methanolic extract of $\mathrm{CcB}$ bark using the micronucleus assay in Swiss albino mice treated once a week with three extract concentrations (312.5; 625 and $1,250 \mathrm{mg} \mathrm{kg}^{-1}$ i.g.) for 28 days. The results revealed the absence of genotoxic activity for the three concentrations tested.

Another study carried out with $\mathrm{CcB}$ revealed the absence of genotoxic activity using t-DCTN, the most important diterpene isolated form the plant bark. t-DCTN was administered as a single dose via intraperitoneal injection in Swiss albino mice. The genotoxic analysis was carried out using the micronucleus test and chromosomal aberrations in bone marrow cells ${ }^{(1)}$.

In the light of the negative results of the study above, Agner et al. ${ }^{(1)}$ assessed the antimutagenic activity of t-DCTN in the same animals using cyclofosfamide as inducer of genetic damage and the micronucleus and chromosomal aberration assays as investigation protocols. The authors chose two t-DCTN treatment approaches: intraperitoneal injection and gavage. In both protocols, the modulator agent was administered 30 min before the i.p. injection of the genotoxic agent as pretreatment. The results obtained in the two bioassays evidenced the antigenotoxic activity of t-DCTN against the genetic damage induced by cyclofosfamide, with both modes of administration.

Based on the results obtained in the present study and those published in the literature, it is possible to conclude that the aqueous and methanolic extracts of $\mathrm{CcB}$ and of t-DCTN (its main constituent agent) are not capable to induce chromosomal loss and/or breakage in bone marrow cells of rodents. Apart from this, t-DCTN presented anti-genotoxic action in mice, by protecting against the induction of clastogenic and/or aneugenic events. Although further studies should be carried out to broaden the spectrum of genotoxic events to be evaluated, $\mathrm{CcB}$ does not seem to pose hazards of genetic damage to humans who ingest the plant extracts.

\section{CONCLUSION}

In summary, treatment with $\mathrm{CcB}$ bark extract did not affect plasmatic glucose and cholesterol levels, but it was able to significantly reduce triglycerides level. There was no significant alteration in hepatic transferase in the control group treated with $\mathrm{CcB}$ bark extract. In diabetic rats, the treatment reduced the plasmatic level of these enzymes. No genotoxic effect of the treatment was observed in the model studied.

\section{ACKNOWLEDGEMENTS}

The authors would like to thank Dr. Claudio Augusto Marroni of "Universidade Federal de Ciências da Saúde de Porto Alegre, RS, Brazil, and Dr. Thêmis Reverbel da Silveira of "Universidade Federal do Rio Grande do Sul" for his wise suggestions.

This study was supported by the FIPE (Financiamento de Pesquisas do Hospital de Clínicas de Porto Alegre) and CAPES.

Rodrigues G, Marcolino E, Porawski M, Lehmann M, Marroni NP. Alterações hepáticas e efeitos genotóxicos do Croton cajucara Benth (SACACA) em ratos diabéticos. Arq Gastroenterol. 2010;47(3):301-5.

RESUMO - Contexto - Croton cajucara Benth é uma planta encontrada na Amazônia, Brasil. Infusões da casca e folhas desta planta são utilizadas popularmente no tratamento de diabetes e doenças hepáticas. Objetivos - Este estudo investigou as alterações hepáticas e os efeitos genotóxicos da casca do extrato do Croton cajucara Benth em animais diabéticos induzidos por estreptozotocina. Métodos - Ratos Wistar machos foram divididos em seis grupos: ratos controle, ratos controle tratados com extrato de Croton cajucara Benth durante 5 e 20 dias, ratos diabéticos e diabéticos tratados com Croton cajucara Benth durante 5 e 20 dias. O diabetes foi induzido por uma única injeção intraperitonial de estreptozotocina (70 mg/kg). Oito semanas mais tarde foram medidos os níveis de glicose, triglicerídios, colesterol e transaminases hepáticas no sangue. O teste do micronúcleo da medula óssea foi utilizado para avaliar a atividade genotóxica do Croton cajucara Benth. Resultados - O tratamento com o extrato aquoso do Croton cajucara foi capaz de reduzir significativamente os níveis plasmásticos dos triglicerídios nos animais diabéticos, porém, não modificaram significativamente os níveis de glicose e colesterol nesses animais. Não houve elevação significativa nas transaminases hepáticas nos animais do grupo controle tratadas com Croton cajucara Benth, assim como também não houve efeito genotóxico do tratamento, no modelo estudado. Conclusãa - O extrato aquoso da casca do Croton cajucara Benth foi hipolipemiante, sugerindo seu uso para prevenir as dislipidemias encontradas em pacientes diabéticos.

DESCRITORES - Doença hepática induzida por drogas. Diabetes mellitus. Croton, toxicidade. Ratos. 


\section{REFERENCES}

1. Agner AR, Maciel MA, Pinto AC, Pamplona SG, Colus IM, Cólus IM. Investigation of genotoxic activity of transdehydrocrotonin, a clerodane diterpene from Croton cajucara. Teratog Carcinog Mutagen. 1999;19:377-84.

2. Bainton D, Miller NE, Botton CH, Yarnell JW, Sweetnam PM, Baker IA, Lewis B, Elwood PC. Plasma triglycerides and high density lipoprotein cholesterol as predictors of ischemic heart disease in British men. The Caerphilly and Speedwell Collaborative Heart Disease Studies Br Heart J. 1992;68:60-6.

3. Biguetti EJ, Souza-Brito AR, de Faria EC, Oliveira HC. Chronic treatment with bark infusion from Croton cajucara lowers plasma triglyceride levels in genetic hyperlipidemic mice. Can J Physiol Pharmacol. 2004;82:387-92.

4. Cartágenes PBR, Moreira CC, Teixeira AC, Silveira FAA, Dias-Junior LB, Bichar CDA, Rodrigues ALS, Bensabath G, Soares MCP. Hepatite por Sacaca (Croton cajucara Benth): epidemiologia clínica em 25 casos [abstract]. GED Gastroenterol Endosc Dig. 1999;18:24.

5. Di Stasi LC, Santos EMG, Santos CM, Hiruma CA. Plantas medicinais da amazônia. São Paulo: Editora UNESP; 1989. p.127-8.

6. El-Hazmi MA, Warsy AS. Evaluation of serum cholesterol and triglyceride levels in 1-6-year-old Saudi children. J Trop Pediatr. 2001;47:181-5.

7. Farias RA, Rao VSN, Viana GSB, Silveira ER, Maciel MAM, Pinto AC Hypoglycemic effect of trans-dehycrotonin, a nor-clerodene diperteno from Croton cajucara. Planta Med. 1997;63:558-60

8. Gerbes AL, Ávila MA, Caselmann WH. Liver injury and liver protection: mechanisms and novel treatment strategies [abstract]. Liver Int. 2006;26:902-3.

9. Goldin JR, Raymundo MM. Pesquisa em saúde e direitos dos animais. $2^{\mathrm{a}}$ ed Porto Alegre: HCPA. 1997.

10. Graim JFS, Lopes-Filho GJ, Brito MVH, Matos LTMB. Histologic evaluation of rats liver after Croton cajucara Benth (sacaca) administration. Acta Cir Bras. 2008;23:130-4.

11. Hiruma-Lima CA, Gracioso JS, Rodriguez JA, Haun M, Nunes DS, SouzaBrito AR. Gastroprotective effect of essential oil from Croton cajucara Benth (Euphorbiaceae). J Ethnopharmacol. 2000;69:229-34.

12. Itokawa H, Ichiara Y, Shimizu M, Takeya K, Motidome M. Cajucarins A and B, new clerodane diterpenes from Croton cajucara, and their conformations. Chem Pharm Bull. 1990;38:701-5.

13. Kesari AN, Kesari S, Singh SK, Gupta RK, Watal G. Studies on the glycemic and lipidemic effect of Murraya koenigii in experimental animals. J Ethnopharmacol. 2007;112:305-11.

14. Lima JMC, Fernandes SG, Alencar ML, Medeiros MTG. Hepatite aguda associada ao uso do Croton cajucara, Benth (sacaca) - Relato de 3 casos. GED Gastroenterol Endosc Dig. 1999;18:38.

15. Luna-Costa AM, Silva JC, Campos AR, Rao VS, Maciel MA, Pinto AC. Antioestrogenic effect of trans-dehydrocrotonin, a nor-clerodane diterpene from C. cajucara Benth in rats. Phytother Res. 1999;13:689-91.
16. MacGregor JT, Heddle JA, Hite M, Margolin BH, Ramel C, Salamone MF, Tice RR, Wild T. Guidelines for the conduct of micronucleus assays in mammalian bone marrow erythrocytes. Mutat Res. 1987;189:103-12.

17. Maciel MAM, Pinto AC, Arruda AC, Pamplona SG, Vanderlinde FA, Lapa AJ, Echevarria A, Cólus IM, Grynberg NF, Farias RA, Luna Costa AM, Rao VS Ethnopharmacology, phytochemistry and pharmacology: a successful combination in the study of Croton cajucara. J Ethnopharmacol. 2000;70:41-55.

18. Maciel MAM, Pinto AC, Veiga VF Jr, Martins JR, Grynberg NF, Echevarria A Lapa AJ, Vanderlinde FA. Croton cajucara as an alternative to traditional medicine in a modern health system. Phytochemistry, Pharmacology. II Ser Recent Prog Med Plants. v. 8, p.502-17, 2002.

19. Maciel MAM, Pinto AC, Veiga Jr VF. Plantas medicinais: a necessidade de estudos multidiscilplinares. Quim Nova. 2002;25:429-38.

20. Maciel MAM, Cortez JKPC, Gomes FES. O gênero Croton e aspectos relevantes de diterpenos clerodanos. Rev Fitos. 2006;2:54-73.

21. Marles RJ, Farnsworth NR. Antidiabetic: plants and their active constituents. Phytomedicine. 1995;2:137-89.

22. Mincis M. Doença hepática induzida por drogas: aspectos de interesse clínico. GED Gastroenterol Endosc Dig. 1985;4:102-8.

23. Opoku AR, Ndlovu IM, Terblanche SE, Hutchings AH. In vivo hepatoprotective effects of Rhoicissus tridenta subsp. cuneifolia, a traditional Zulu medicinal plant, against $\mathrm{CCl}_{4}$ - induced acute liver injury in rats. S Afr J Bot. 2007;73:371-7.

24. Raja S, Ahamed KF, Kumar V, Mukherjee K, Bandyopadhyay A, Mukherjee PK Antioxidant effect of Cytisus scoparius against carbon tetrachloride treated liver injury in rats. J Ethnopharmacol. 2007;109:41-7.

25. Santos FV, Mesquita SFP, Faria MJSS, Poersh A, Maciel MAM, Pinto AC, Morimoto HK, Cólus IMS. Absence of mutagenicity in somatic and germ cells of mice submitted to subchronic treatment with an extract of Croton cajucara Benth (Euphorbiaceae). Genet Mol Biol. 2006;29:159-65.

26. Silva RM, Santos FA, Rao VS, Maciel MA, Pinto AC. Blood glucose- and triglyceride-lowering effect of transdehydrocrotonin, a diterpene from Croton cajucara Benth. in rats. Diabetes Obes Metab. 2001;3:452-6.

27. Soares MC. Would sacaca, Croton cajucara Benth (Euphorbiaceae) be an hepatotoxic plant like Germander, Teucrium chamaedrys L. (Labiatae)? Rev Soc Bras Med Trop. 2004;37:96-9.

28. Van Den Berg ME. Plantas medicinais na amazônia - Contribuição ao seu conhecimento sistemático. Belém: Museu Paraense Emilio Goeldi; 1982. 223p.

29. Veiga Jr VF, Pinto AC, Maciel MAM. Medicinal plants: safe cure? Quim Nova. 2005;28:519-28.

30. Venkateswaran S, Pari L, Viswanathan P. Anti peroxidation effect of Livex, a herbal formulation against erythromycin estolate induced lipid peroxidation in rats. Phytother Res. 1998;12:465-71. 